\title{
A novel mutation in the tyrosine kinase domain of ERBB2 in hepatocellular carcinoma Tanios Bekaii-Saab*1,2, Nita Williams ${ }^{4}$, Christoph Plass ${ }^{4}$, Miguel Villalona Calero ${ }^{1,2}$ and Charis Eng $3,4,5$
}

\begin{abstract}
Address: ${ }^{1}$ Division of Hematology and Oncology, Department of Internal Medicine, Comprehensive Cancer Center, The Ohio State University, Columbus, Ohio, USA, ${ }^{2}$ Department of Pharmacology, The Ohio State University, Columbus, Ohio, USA, ${ }^{3}$ Division of Human Genetics, Department of Internal Medicine, Comprehensive Cancer Center, The Ohio State University, Columbus, Ohio, USA, ${ }^{4}$ Department of Molecular Virology, Immunology and Medical Genetics; Human Cancer Genetics Program, Comprehensive Cancer Center, The Ohio State University, Columbus, Ohio, USA and ${ }^{5}$ Genomic Medicine Institute and Taussig Cancer Center, Cleveland Clinic Foundation, Cleveland, Ohio, USA

Email: Tanios Bekaii-Saab* - Tanios.Bekaii-Saab@osumc.edu; Nita Williams - Nita.Williams@osumc.edu; Christoph Plass - Christoph.Plass@osumc.edu; Miguel Villalona Calero - Miguel.Villalona@osumc.edu; Charis Eng - engc@ccf.org

* Corresponding author
\end{abstract}

Published: 06 December 2006

BMC Cancer 2006, 6:278 doi:10.1186/147|-2407-6-278
Received: 24 August 2006

Accepted: 06 December 2006

This article is available from: http://www.biomedcentral.com//47I-2407/6/278

(c) 2006 Bekaii-Saab et al; licensee BioMed Central Ltd.

This is an Open Access article distributed under the terms of the Creative Commons Attribution License (http://creativecommons.org/licenses/by/2.0), which permits unrestricted use, distribution, and reproduction in any medium, provided the original work is properly cited.

\begin{abstract}
Background: Several studies showed that gain-of-function somatic mutations affecting the catalytic domain of EGFR in non-small cell lung carcinomas were associated with response to gefitinib and erlotinib, both EGFR-tyrosine kinase inhibitors. In addition, $4 \%$ of non-small cell lung carcinomas were shown to have ERBB2 mutations in the kinase domain. In our study, we sought to determine if similar respective gain-of-function EGFR and ERBB2 mutations were present in hepatoma and/or biliary cancers.
\end{abstract}

Methods: We extracted genomic DNA from 40 hepatoma (18) and biliary cancers (22) samples, and 44 adenocarcinomas of the lung, this latter as a positive control for mutation detection. We subjected those samples to PCR-based semi-automated double stranded nucleotide sequencing targeting exons 18-2I of EGFR and ERBB2. All samples were tested against matched normal DNA.

Results: We found II\% of hepatoma, but no biliary cancers, harbored a novel ERBB2 H878Y mutation in the activating domain.

Conclusion: These newly described mutations may play a role in predicting response to EGFRtargeted therapy in hepatoma and their role should be explored in prospective studies.

\section{Background}

Mutations in the protein-kinase enzyme family, such as the epidermal growth factor receptor (EGFR, ERBB2), found in human cancers are being investigated as promising targets for the development of novel antitumor therapies.EGFR is the first described member of a family of related transmembrane receptor tyrosine kinases. It is comprised of the following four related receptors: EGFR itself (ERBB1 or HER1), ERBB2 (HER2/neu), ERBB3 (HER3) and ERBB4 (HER4). ERBB receptors are composed of an extracellular ligand-binding domain, a transmembrane segment, and an intracellular protein tyrosine kinase domain. These receptors trigger downstream signaling pathways that are complex and multilayered. Deregulation of those ERBB receptors can lead to malignant transformation. These receptors form either homo- or het- 
erodimeric complexes which provides amplification and diversification [1]. Heterodimerization of the ERBB2 and $E G F R$ is associated with a more robust signaling than homodimerization [2]. Several studies showed that gainof-function somatic mutations affecting the catalytic domain (specifically the ATP binding site, exons 18-21) of EGFR in non-small cell lung carcinomas were strongly associated with response to gefitinib and erlotinib, both related EGFR-tyrosine kinase inhibitors (TKI) [3-5]. More recently, a number of studies reported the presence of ERBB2 mutations located in the kinase domain (exons 19 and 20) in non-small cell lung carcinomas (NSCLC) that could potentially result in the activation of the tyrosine kinase activity of the receptor protein [6-9]. In addition to NSCLC, mutations in the ERBB2 kinase domain were described in gastric, colorectal, and breast cancers $[10,11]$. In our study, we sought to determine if similar respective gain-of-function EGFR and ERBB2 mutations were present in hepatoma and biliary cancers to determine the potential for $E R B B$-targeted therapy.

Hepatoma is the most common malignant tumor of the liver with a clear rising incidence in the number of cases in the United States, and is largely attributed to the increase in hepatitis $\mathrm{C}$ related liver disease [12]. Cancers of the biliary tract are the second most common primary hepatobiliary cancer [13]. There is no satisfactory treatment available for patients with hepatobiliary cancers and chemotherapy has been extremely disappointing.

The poor prognosis of patients with hepatoma and biliary cancers in addition to the lack of satisfactory therapy for advanced cases indicates a need for more effective therapeutic options. EGFR signaling is implicated in both hepatic and biliary carcinogenesis. Studies indicate that EGFR is expressed in up to $85 \%$ and $80 \%$ of hepatoma and biliary cancers, respectively [14], and EGF might be required for the growth of those cells $[15,16]$. ERBB2 is also expressed in a significant number of hepatoma and biliary cancers acting as an independent prognostic factor and a major contributor to carcinogenesis [17-21]. Recently, a multi-center phase 2 study looked at the efficacy and tolerability of erlotinib in advanced hepatoma and biliary cancers with encouraging results $[22,23]$. In hepatoma, the reported PFS at 6 months of 32\% with disease control (PR + SD) of $59 \%$ for a median duration of 4 months. The median overall survival (OS) was 13 months. In biliary cancers, the reported PFS at 6 months was $25 \%$ with disease control (PR + SD) of $55 \%$ for a median duration of 5.4 months. The median OS was 9 months.

\section{Methods}

In our study, we extracted genomic DNA from 40 hepatoma (18) and biliary cancers (22) samples, and 44 adenocarcinoma of the lung, the latter as a positive control for mutation detection. All hepatobiliary samples were paraffin-embedded while all lung samples were frozen. Hepatoma and biliary cancers were subjected to laser capture microdissection as previously described (Kurose $\mathrm{K}$ et al. Hum Mol Genet 2001) to enrich the neoplastic component. We subjected those samples to PCR-based semiautomated double stranded nucleotide sequencing, per routine of the Eng lab $[24,25]$. Exons 18-21 (exon-intron junctions and flanking intronic regions) of EGFR were amplified using the primers and conditions described by Lynch et al [3] and those of ERBB2 were amplified using the primers and conditions described by Stephens et al [6]. Double stranded sequencing was performed with the ABI-3700. Mutations or variants were confirmed in both directions as well as confirmed by a second independent PCR reaction. All samples were tested against matched germline DNA derived from the related normal organ. Our samples were acquired on anonymised archived materials without personal identifiers, on an exempt protocol approved by the Ohio State University Institutional Review Board.

\section{Results}

All hepatoma and biliary cancers samples were negative for gain-of-function somatic mutations affecting the catalytic domain of the EGFR gene. Power calculations suggest that our negative results predict that no more than $3 \%$ of hepatoma or biliary cancers would eventually be found to carry such mutations. As a positive control for mutation detection, we sequenced EGFR exons 18-21 in 44 adenocarcinoma of the lung and found $2(5 \%)$ with somatic delE746-A750 mutations, previously reported to be associated with gefitinib responsiveness. In contrast, 2 (11\%) of the 18 hepatoma had a single novel somatic $\mathrm{H} 878 \mathrm{Y}$ (CAT to TAT; c.2632C > T) mutation in exon 21 of ERBB2 (figure 1), while none of the biliary cancers were found to have somatic mutations. None of the matched normal tissue was found to have somatic mutations for EGFR or $E R B B 2$ found in the tumors. These are different from the reported mutations in non-small cell lung carcinomas. The H878Y missense mutation occurring in the activation domain of ERBB2 alters a basic hydrophilic residue to an acidic hydrophilic residue, and so is predicted to affect function.

\section{Discussions and Conclusion}

The lack of effective treatment for hepatobiliary tumors indicates a need for more effective therapeutic options. Emerging targeted therapies including EGFR inhibitors are offering promise in a variety of malignancies including hepatobiliary tumors. From this study, we conclude that gain-of-function somatic mutations affecting the catalytic domain of EGFR as described in non-small cell lung carcinomas have a predicted low yield in hepatoma and biliary 


\section{EGFR2/ERBB2 Exon 21}

\section{HCC DNA}

130140150

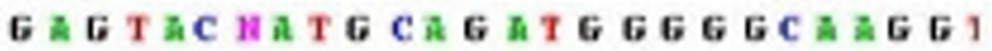

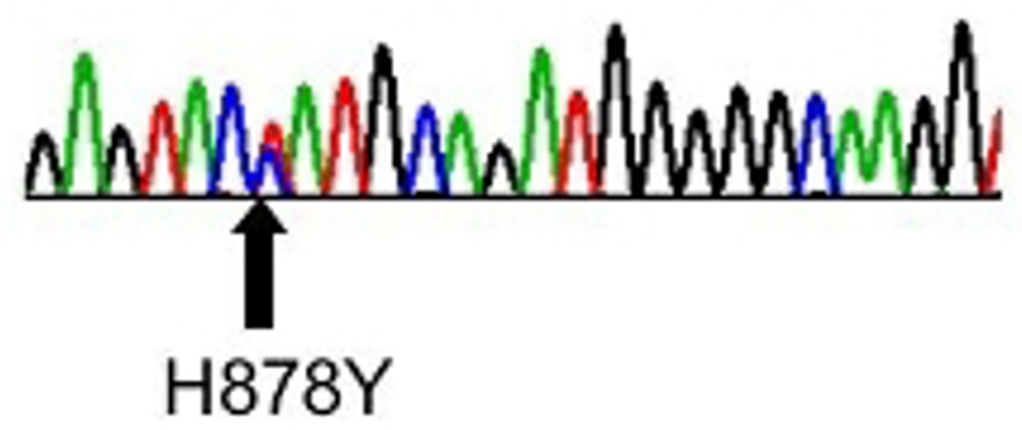

\section{Matched normal DNA}

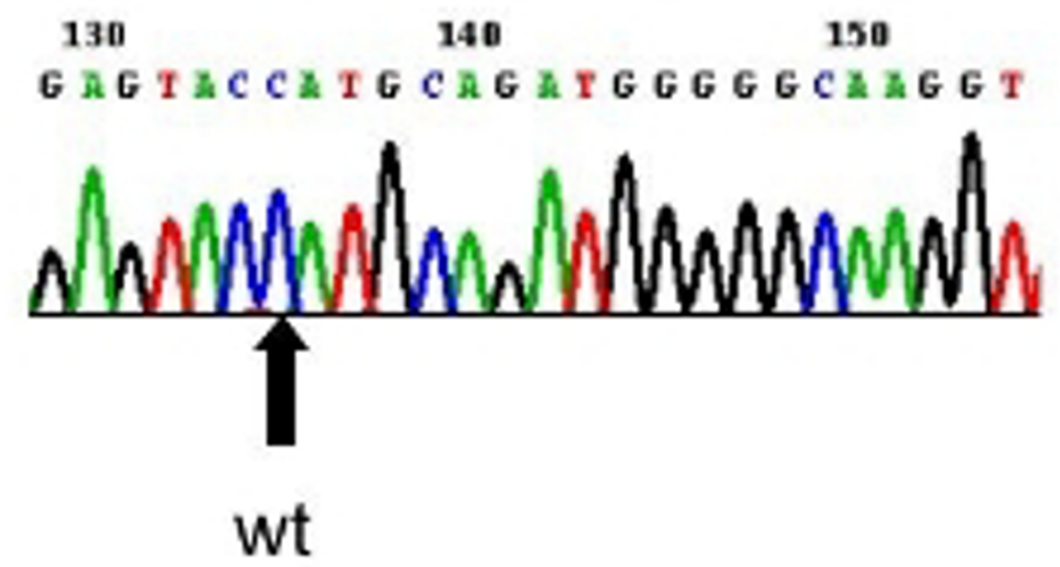

Figure I

Somatic missense mutation, H878Y, found in genomic DNA from hepatoma (top chromatogram) but not in corresponding normal tissue (bottom panel). 
cancers. A recently published study showed the lack of somatic mutations in EGFR tyrosine kinase domain in 100 hepatocellular carcinomas confirming our findings [26]. In contrast, we showed that $11 \%$ of hepatocellular carcinomas tested have an ERBB2 mutation occurring in the activation domain. None were found in biliary cancer specimens. Given the availability of agents interfering with ERBB2 signaling and the established role of ERBB2 in the EGFR signaling pathway, we speculate that these newly described mutations may play a role in predicting response to EGFR-targeted therapy in hepatoma in predicting response to agents that target ERBB2 and/or EGFR in hepatoma. Interestingly, one such agent, lapatinib (a dual EGFR/ERBB2 TKI), was recently reported to have activity in hepatomas (TGCR $=40 \%$ ) but not in biliary cancers (TGCR $=26 \%$ ) [27]. Cohen et al showed that in head and neck cancers although responses to gefitinib or erlotinib were not linked to kinase mutations of EGFR, one single response case was actually linked to a mutation in exon 20 of ERBB2 establishing the potential predictive value of such mutations on responses to agents that target ERBB2 and/or EGFR [28]. In conclusion, our findings suggest that mutations in the tyrosine kinase domain of $E R B B 2$ in hepatoma may underlie responsiveness to agents that target ERBB2 and/or EGFR. This should trigger similar analysis as part of correlative studies in prospective studies.

\section{Competing interests}

The author(s) declare that they have no competing interests.

\section{Authors' contributions}

TBS conceived the study in collaboration with CE, was involved in the coordination of the study and drafted the manuscript. NW carried out the technical aspects of the mutation analysis of EGFR/ERBB2. CP made substantial contributions to conception and design and interpretation of data. MVC participated in the design of the study and was involved in revising the manuscript for intellectual content. CE conceived the study in collaboration with TBS, supervised the conduct of the study and helped draft the manuscript. All authors read and approved the final manuscript.

\section{Acknowledgements}

CE is a recipient of the Doris Duke Distinguished Clinical Scientist Award and is a National Scholar of the Dorothy M. Davis Heart and Lung Research Institute of The Ohio State University.

\section{References}

I. Mendelsohn J, Baselga J: Status of epidermal growth factor antagonists in the biology and treatment of cancer. J Clin Oncol 2003, 27:2787-2799.

2. Lillemoe KD: Cancers of the Biliary Tree: Clinical Management. In Gastrointestinal Oncology, Principles and Practice Ist edition. Edited by: Kelsen KP, Daly JM, Kern SE, Levin B, Tepper JE. Philadelphia. Lippincott Willaims and Wilkins; 2002:645-662.
3. Lynch TJ, Bell DW, Sordella R, Gurubhagavatula S, Okimoto RA, Brannigan BW, Harris PL, Haserlat SM, Supko JG, Haluska FG, Louis DN, Christiani DC, Settleman J, Haber DA: Activating mutations in the epidermal growth factor receptor underlying responsiveness of non-small-cell lung cancer to gefitinib. N EnglJ Med 350(2I):2I29-39. 2004 May 20

4. Paez JG, Janne PA, Lee JC, Tracy S, Greulich H, Gabriel S, Herman P, Kaye FJ, Lindeman N, Boggon TJ, Naoki K, Sasaki H, Fujii Y, Eck MJ, Sellers WR, Johnson BE, Meyerson M: EGFR mutations in lung cancer: correlation with clinical response to gefitinib therapy. Science 304(5676): 1497-500. 2004 Jun 4

5. Pao W, Miller V, Zakowski M, Doherty J, Politi K, Sarkaria I, Singh B, Heelan R, Rusch V, Fulton L, Mardis E, Kupfer D, Wilson R, Kris M, Varmus H: EGF receptor gene mutations are common in lung cancers from "never smokers" and are associated with sensitivity of tumors to gefitinib and erlotinib. Proc Natl Acad Sci USA I0I(36): I3306-II. 2004 Sep 7

6. Stephens P, Hunter C, Bignell G, Edkins S, Davies H, Teague J, Stevens C, O'Meara S, Smith R, Parker A, Barthorpe A, Blow M, Brackenbury L, Butler A, Clarke O, Cole J, Dicks E, Dike A, Drozd A, Edwards K, Forbes S, Foster R, Gray K, Greenman C, Halliday K, Hills K, Kosmidou V, Lugg R, Menzies A, Perry J, Petty R, Raine K, Ratford L, Shepherd R, Small A, Stephens Y, Tofts C, Varian J, West S, Widaa S, Yates A, Brasseur F, Cooper CS, Flanagan AM, Knowles M, Leung SY, Louis DN, Looijenga LH, Malkowicz B, Pierotti MA, Teh B, ChenevixTrench G, Weber BL, Yuen ST, Harris G, Goldstraw P, Nicholson AG, Futreal PA, Wooster R, Stratton MR: Lung cancer: intragenic ERBB2 kinase mutations in tumours. Nature 43I(7008):525-6. 2004 Sep 30

7. El-Serag HB, Mason AC: Rising incidence of hepatocellular carcinoma in the United States. N Eng J Med 1999, 340(10):745-750.

8. Roskoski $\mathrm{R}$ Jr: The ErbB/HER receptor protein-tyrosine kinases and cancer. Biochem Biophys Res Commun 319(I): I-II. 2004 Jun 18

9. Altimari A, Fiorentino M, Gabusi E, Gruppioni E, Corti B, D'Errico A, Grigioni WF: Investigation of ErbB I and ErbB2 expression for therapeutic targeting in primary liver tumours. Dig Liver Dis 2003, 35(5):332-8.

10. Ito Y, Takeda T, Sakon M, Tsujimoto M, Higashiyama S, Noda K, Miyoshi E, Monden M, Matsuura N: Expression and clinical significance of erb-B receptor family in hepatocellular carcinoma. Br J Cancer 84( (10): 1377-83. 2001 May 18

II. Ito Y, Takeda T, Sasaki Y, Sakon M, Yamada T, Ishiguro S, Imaoka S, Tsujimoto M, Higashiyama S, Monden M, Matsuura N: Expression and clinical significance of the erbB family in intrahepatic cholangiocellular carcinoma. Pathol Res Pract 200I, 197(2):95-100.

12. Huang BJ, Huang TJ, Liang QW, Huang CW, Fang Y: Quantitative detection of HER-2 oncogene amplification in primary hepatocellular carcinoma using dual FISH technique and its clinical significance. Yi Chuan Xue Bao 200 I, 28(9):793-800.

13. Su Q, Liu Y: Expression of c-erbB-2 protein and EGF receptor in hepatitis B, cirrhosis and hepatocellular carcinoma. Zhonghua Bing Li Xue Za Zhi 1995, 24(2):93-5.

14. Chow NH, Huang SM, Chan SH, Mo LR, Hwang MH, Su WC: Significance of c-erbB-2 expression in normal and neoplastic epithelium of biliary tract. Anticancer Res 1995, I 5(3): 1055-9.

I5. Ito $Y$, Takeda $T$, Sasaki $Y$, Sakon $M$, Yamada T, Ishiguro S, Imaoka S, Tsujimoto M, Higashiyama S, Monden M, Matsuura N: Expression and clinical significance of the erbB family in intrahepatic cholangiocellular carcinoma. Pathol Res Pract 200I, 197(2):95-100.

16. Ukita $Y$, Kato $M$, Terada $T$ : Gene amplification and mRNA and protein overexpression of c-erbB-2 (HER-2/neu) in human intrahepatic cholangiocarcinoma as detected by fluorescence in situ hybridization, in situ hybridization, and immunohistochemistry. J Hepatol 2002, 36(6):780-5.

17. Philip PA, Mahoney M, Thomas J, Pitot H, Donehower R, Kim G, Picus J, Fitch T, Geyer S, Erlichman C: Phase II Trial of erlotinib (OSI774) in patients with hepatocellular or biliary cancer. Journal of Clinical Oncology, 2004 ASCO Annual Meeting Proceedings (Post-Meeting Edition) 2004, 22(I4S (July I 5 Supplement)):4025.

18. Philip PA, Mahoney MR, Allmer C, Thomas J, Pitot HC, Kim G, Donehower RC, Fitch T, Picus J, Erlichman C: Phase II study of Erlotinib 
(OSI-774) in patients with advanced hepatocellular cancer. J Clin Oncol 23(27):6657-63. 2005 Sep 20

19. Mutter GL, Lin MC, Fitzgerald JT, Kum JB, Baak JP, Lees JA, Weng LP, Eng C: Altered PTEN expression as a diagnostic marker for the earliest endometrial precancers. I Natl Cancer Inst 92(II):924-30. 2000 Jun 7

20. Kurose K, Gilley K, Matsumoto S, Watson PH, Zhou XP, Eng C: Frequent somatic mutations in PTEN and TP53 are mutually exclusive in the stroma of breast carcinomas. Nat Genet 2002, 32(3):355-7.

21. Ukita $Y$, Kato $M$, Terada T: Gene amplification and mRNA and protein overexpression of c-erbB-2 (HER-2/neu) in human intrahepatic cholangiocarcinoma as detected by fluorescence in situ hybridization, in situ hybridization, and immunohistochemistry. J Hepatol 2002, 36(6):780-5.

22. Philip PA, Mahoney M, Thomas J, Pitot H, Donehower R, Kim G, Picus J, Fitch T, Geyer S, Erlichman C: Phase II Trial of erlotinib (OSI774) in patients with hepatocellular or biliary cancer. Journal of Clinical Oncology, 2004 ASCO Annual Meeting Proceedings (Post-Meeting Edition) 2004, 22(I 4S (July I5 Supplement)):4025.

23. Philip PA, Mahoney MR, Allmer C, Thomas J, Pitot HC, Kim G, Donehower RC, Fitch T, Picus J, Erlichman C: Phase II study of Erlotinib (OSI-774) in patients with advanced hepatocellular cancer. I Clin Oncol 23(27):6657-63. 2005 Sep 20

24. Mutter GL, Lin MC, Fitzgerald JT, Kum JB, Baak JP, Lees JA, Weng LP, Eng C: Altered PTEN expression as a diagnostic marker for the earliest endometrial precancers. I Natl Cancer Inst 92(II):924-30. 2000 Jun 7

25. Kurose K, Gilley K, Matsumoto S, Watson PH, Zhou XP, Eng C: Frequent somatic mutations in PTEN and TP53 are mutually exclusive in the stroma of breast carcinomas. Nat Genet 2002, 32(3):355-7.

26. Cohen EE, Lingen MW, Martin LE, Harris PL, Branningan BW, Haserlat SM, Okimoto RA, Sgroi DC, Dahiya S, Muir B, Clark JR, Rocco JW, Vokes EV, Haber DA, Bell DW: Response of Some Head and Neck Cancers to Epidermal Growth Factor Receptor Tyrosine Kinase Inhibitors May be Linked to Mutation of ERBB2 rather than EGFR. Clin Cancer Res I I (22):8I05-8. 2005 Nov I5

27. Ramanathan RK, Belani CP, Singh DA, Tanaka M, Lenz HJ, Yen Y, Kindler HL, lqbal S, J J, Gandara DR: Phase II study of lapatinib, a dual inhibitor of epidermal growth factor receptor (EGFR) tyrosine kinase $I$ and 2 (Her2/Neu) in patients (pts) with advanced biliary tree cancer (BTC) or hepatocellular cancer (HCC). A California Consortium (CCC-P) Trial. Journal of Clinical Oncology, 2006 ASCO Annual Meeting Proceedings Part I 2006, 24( 185 (June 20 Supplement)): 4010.

28. Lee SC, Lim SG, Soo R, Hsieh WS, Guo JY, Putti T, Tao Q, Soong R, Goh BC: Lack of Somatic Mutations in EGFR Tyrosine Kinase Domain in Hepatocellular and Nasopharyngeal Carcinoma. Pharmacogenet Genomics 2006, 16(1):73-4.

\section{Pre-publication history}

The pre-publication history for this paper can be accessed here:

http://www.biomedcentral.com/1471-2407/6/278/pre pub
Publish with Biomed Central and every scientist can read your work free of charge

"BioMed Central will be the most significant development for disseminating the results of biomedical research in our lifetime. "

Sir Paul Nurse, Cancer Research UK

Your research papers will be:

- available free of charge to the entire biomedical community

- peer reviewed and published immediately upon acceptance

- cited in PubMed and archived on PubMed Central

- yours - you keep the copyright

Submit your manuscript here:

http://www.biomedcentral.com/info/publishing_adv.asp
BioMedcentral 